\title{
Role Of Vincristine In Treatment Of Refractory Idiopathic Thrombocytopenic Purpura (Itp)
}

\author{
Ahmad F. Thabet ${ }^{1,}$ Medhat A Saleh ${ }^{2}$ and Mostafa M. Sayed ${ }^{3}$ \\ ${ }^{I}$ Department of Internal Medicine ${ }^{2}$ Public Health and Community Medicine, ${ }^{3}$ Surgery Department, Faculty of \\ Medicine, Assiut University, Egypt
}

\begin{abstract}
Chronic immune thrombocytopenia (ITP) is a condition associated with significant morbidity; however the management options for refractory ITP are often unsatisfactory despite various lines of treatment including splenectomy. The comparison of vincristine costs with other lines of treatment as intravenous immunoglobulin revealed many folds lower costs of vincristine. The aims of this study are: to evaluate the role of vincristine in treating (splenectomized and non splenectomized) refractory ITP patients who are resistant to corticosteroids therapy, to assess the use of vincristine in clinical situations requiring increase in the platelet count as a preoperative management and to evaluate the long term (6 months) follow up effect after stoppage of vincristine treatment in refractory ITP patients. Patients and Methods: Twenty nine refractory ITP patients with maximum dose of corticosteroids ( 21 of them non-splenectomized "group I" and the remaining 8 splenectomized "group II") were treated with two- hour intravenous infusion of vincristine (1-2 mg) once a week for 6 weeks. In every patient, the platelet count was evaluated just before and just after the infusion of vincristine, follow up of these patients for 6 months after stoppage of vincristine was by evaluating platelet count every 2 months. Patients with hepatitis and chronic liver diseases were excluded from this study. Results: a significant increased level of the mean platelet count was observed in "group I" after the 2nd week of vincristine treatment $(p<0.005)$ and after the $3 r d, 4 t h, 5$ th and 6 th week of vincristine treatment $(p<0.001)$ when compared to before the use of vincristine. Also there was statistically significant increase of the mean platelet count in "group II" after the 3rd, 4th, 5th and 6th weeks of vincristine treatment than before the use of vincristin treatment $(p<0.05)$ for all comparison, the study also revealed that " group II" had a significantly increased mean platelet count than "group I" after the 4th week of vincristine treatment $(p<0.05)$, while no significant differences could be detected after the 1 st $, 2 n d, 3 \mathrm{rd}, 5$ th and 6 th weeks of vincristine treatment. A persistent increase of the mean platelet count was observed after 2,4 and 6 months follow up after stoppage of vincristine treatment when compared with the mean platelet count before the use of vincristin treatment in "group I" ( $p<0.001, p<0.05$ and $p<0.05)$ respectively and in "group II" ( $p<0.05)$ for all comparisons. Higher mean value of platelet count was observed after 4 and 6 months of stoppage of vincristine treatment among "group II" than "group I" with no statistically significant difference, while this comparison was statistically significant after 2 months of stoppage of vincristine treatment $(p<0.05)$. Conclusion: Administration of vincristine to chronic corticosteroid refractory (ITP) patients was associated with a significant increased platelet count in both non splenectomized "group I" and splenectomized "group II" and this increase was persistent after stoppage of vincristine treatment for 6 month.
\end{abstract}

\section{Introduction}

Immune thrombocytopenic purpura (ITP) is also known as idiopathic thrombocytopenic purpura (Cooper and Bussel, 2006). It is an autoimmune disorder characterized by immunologic destruction of otherwise normal platelets most commonly occurring in response to an unknown stimulus. ITP may occur as primary or in association with other disorders (secondary) Cindy et al., 2011. The clinical course of ITP is usually chronic in adults. In cases of chronic ITP, serious bleeding is not expected even with significant thrombocytopenia. The mortality rate due to bleeding secondary to ITP is less than $1 \%$ (George , 2009), but it is associated with significant morbidity; however the management options are often unsatisfactory with a portion of patients exhibiting a refractory-relapsing disease path despite various lines of treatment including splenectomy (Alhossain et al ., 2012).

Corticosteroids are given as the first line of therapy in ITP cases with serious thrombocytopenia. Splenectomy is the standard care for cases that are non-responsive to corticosteroids. The rate of complete remission is 66\% (British Committee, 2003). The treatment of referactory ITP is often difficult ( Ahn et al., 1974). When a beneficial response is not achieved, the disease is said to be refractory (Karpatkin et al., 1972). Various post-splenectomy treatments have been administered to refractory patients as azathioprine, vinka alkaloids, danazol, cyclophosphamide, high dose dexamethasone, rituximab, interferon, and cyclosporine have been used. The treatment of chronic refractory ITP is difficult because response to treatment is variable (Vesely 
et al., 2004). Vincristine can produce responses in platelet counts after days to weeks of administration with considerable variability in response by individual patients (Provan et al., 2010).

No optimal treatment is currently available for patients with chronic ITP who were resistant to splenectomy (Murat et al., 2010). It has been pointed out that vincristine could be more effective in splenectomized patients (Ries, 1976). Administration of vinca alkaloids (VA) to chronic corticosteroid refractory immune thrombocytopenia ITP patients results in a temporary increase of platelet count (Szczepanik et al.,2007) and considered to be an useful treatment in patients with ITP (Matsushima et al., 1992).Vincristine having the advantage of a faster action (Ahn et al.,1974) and could find their application in clinical situations requiring short-term increase of the platelet count in chronically ill patients with ITP, resistant to corticosteroids or with contraindication to their application ( Sikorska et al.,2004), because of this, its use has been recommended for producing a rise in the platelet count before splenectomy or to control bleeding (Burton et al.,1976).

Matching of vincristine costs with treatment efficacy and comparison with the costs of intravenous immunoglobulin treatment revealed many folds lower costs of the vincristive method (Szczepanik et al., 2007). (Shvidel et al ., 2006) reported that vincristine-loaded platelet infusion in patients with refractory (ITP)who failed to respond to two to six different treatment modalities, including corticosteroids and splenectomy was prompt and useful approach in patients with ITP refractory to primary therapy.

\section{Patients and methods}

\section{1-Study Site:}

The patients were chosen from those admitted to Clinical Hematology Unit, Internal Medicine Department, Assiut University Hospitals and from Assiut Health Insurance.

\section{2-Study Design:}

One arm experimental clinical trail hospital based study

\section{3- Study population sample size:}

Twenty nine refractory ITP patients( 21 of them non-splenectomized "group I" 14 females and 7 males and the remaining 8 splenectomized "group II" 6 females and 2 males) were previously diagnosed as ITP on the basis of history, Clinical data and examination of peripheral blood and marrow smears.

\section{4-Technical design:}

All those patients had been unsuccessfully treated with corticosteroids therapy with its maximum dose and even after high dose of dexamethason IV (24-32 mg/day) for four days. The patients were chosen from those admitted to Clinical Hematology Unit, Internal Medicine Department, Assiut University Hospitals and from Assiut Health Insurance. Full history taking and thorough clinical examination were done for all studied patients. Follow up complete blood counts - on automated cell counter MAX-M coultronics, France-were performed for all patients before and after every dose of vincristine infusion (1-2mg once a week for 6 weeks) and follow up of those patients after stoppage of vincristine treatment for 6 months were evaluated by complete blood counts every 2 months. Patients with secondary ITP or with chronic liver diseases were excluded.

\section{5- Ethical consideration}

Patients were invited to participate in the study on their full well and the steps and aim of the research were explained to participants before taking verbal consent.

\section{Statistical analysis:}

Data were analyzed and expressed as mean values \pm standard deviations (SD). SPSS version 16 program was used for data processing. Differential semen concentration of lead and cadmium was determined by dividing their seminal concentrations on serum concentration in the same subject. Unpaired t-test has been used in comparison of numerical parametric data between patient and control groups. Mann-Whitney test was used in comparison of numerical non parametric data between patient and control groups. Pearson correlation test was applied to analyze correlations between different quantitative variables within each group. Values were considered significant when $P$ values were equal or less than 0.05 . 


\section{Results}

Table 1: Age and sex distribution of the studied patients

\begin{tabular}{|c|c|c|c|c|}
\hline \multirow[t]{2}{*}{ Variables } & \multicolumn{2}{|c|}{$\begin{array}{l}\text { Non splenectomized } \\
\text { Group I (21) }\end{array}$} & \multicolumn{2}{|c|}{$\begin{array}{l}\text { Splenectomized } \\
\text { Group II (8) }\end{array}$} \\
\hline & No & $\%$ & No & $\%$ \\
\hline $\begin{array}{ll}\text { Sex } & \\
\bullet & \text { Males } \\
\bullet & \text { Females }\end{array}$ & $\begin{array}{c}7 \\
14\end{array}$ & $\begin{array}{l}24.1 \% \\
48.3 \%\end{array}$ & $\begin{array}{l}2 \\
6\end{array}$ & $\begin{array}{l}6.8 \% \\
20.6 \%\end{array}$ \\
\hline $\begin{array}{l}\text { Age (years) } \\
\text { Mean } \pm \text { SD }\end{array}$ & \multicolumn{2}{|c|}{$30.6 \pm 8.9$} & \multicolumn{2}{|c|}{$31.7 \pm 10.8$} \\
\hline
\end{tabular}

This study showed that the total number of patients was 29 patients ( 21 non splenctomized "group I" , 7 males, 14 females ; mean age $\pm \mathrm{SD}=30.6 \pm 8.9$ years, range $16-45$ years $)$ and ( 8 splenctomized patients "group 2" , 2 males and 6 females; mean age $\pm \mathrm{SD}=31.7 \pm 10.8$ years, range $23-44$ years.

Table (2): Platelet count before and after vincristine therapy in the studied sample

\begin{tabular}{|c|c|c|}
\hline \multirow[b]{2}{*}{ Platelet count } & \multicolumn{2}{|c|}{$\begin{array}{c}\text { Mean platelet count } \times 10^{9} / \mathrm{L} \pm \text { S.D } \\
\text { (Range) }\end{array}$} \\
\hline & $\begin{array}{c}\text { Non splenectomized Patients } \\
\text { Group I } \\
(\text { no=21) }\end{array}$ & $\begin{array}{c}\text { Splenectomized Patients } \\
\text { Group II } \\
(\text { no= }=8)\end{array}$ \\
\hline Before vincristine treatment & $\begin{array}{c}11.3 \pm 6.1 \\
(4: 24) \\
\end{array}$ & $\begin{array}{c}17 \pm 4.53 \\
(12: 21) \\
\end{array}$ \\
\hline $\begin{array}{l}2 . \quad \text { After one week of } \\
\text { vincristine treatment }\end{array}$ & $\begin{array}{c}11.4 \pm 5.1 \\
(4: 21)\end{array}$ & $\begin{array}{l}16 \pm 3.5 \\
(12: 21)\end{array}$ \\
\hline $\begin{array}{l}\text { 3. After two weeks of } \\
\text { vincristine treatment }\end{array}$ & $\begin{array}{c}16.7 \pm 7.2 \\
(6: 30)\end{array}$ & $\begin{array}{c}22.5 \pm 9.1 \\
(10: 35)\end{array}$ \\
\hline $\begin{array}{l}4 . \quad \text { After three weeks of } \\
\text { vincristine treatment }\end{array}$ & $\begin{array}{c}37.1 \pm 22.47 \\
(7: 70)\end{array}$ & $\begin{array}{c}41.75 \pm 25.79 \\
(8: 70)\end{array}$ \\
\hline $\begin{array}{l}5 . \quad \text { After four weeks of } \\
\text { vincristine treatment }\end{array}$ & $\begin{array}{l}53.76 \pm 34.82 \\
(5: 96)\end{array}$ & $\begin{array}{l}78.87 \pm 59.47 \\
(8: 140)\end{array}$ \\
\hline $\begin{array}{l}\text { 6. After five weeks of } \\
\text { vincristine treatment }\end{array}$ & $\begin{array}{c}94.86 \pm 71.29 \\
(6: 200)\end{array}$ & $\begin{array}{c}103.87 \pm 79.11 \\
(8: 190)\end{array}$ \\
\hline $\begin{array}{l}\text { 7. After six weeks of } \\
\text { vincristine treatment }\end{array}$ & $\begin{array}{c}80.03 \pm 60.73 \\
(4: 200)\end{array}$ & $\begin{array}{c}111.5 \pm 84.54 \\
(8: 200)\end{array}$ \\
\hline
\end{tabular}

This table revealed that the mean platelet count was $\left(11.3+6 \times 10^{9} / \mathrm{L}\right)$ in "group I" before the vincristine therapy and increased to reach its maximum level after the fifth and six weeks of vincristine therapy $(94.8 \pm$ 71.2 and $\left.80 \pm 60.7 \times 10^{9} / \mathrm{L}\right)$ respectively, and in "group II" was $\left(17 \pm 4.53 \times 10^{9} / \mathrm{L}\right)$ and increased to $(78.87 \pm 59.47,103.87 \pm 79.11$ and $111.5 \pm 84.54)$ after the fourth, fifth and six weeks of vincristine therapy respectively. 


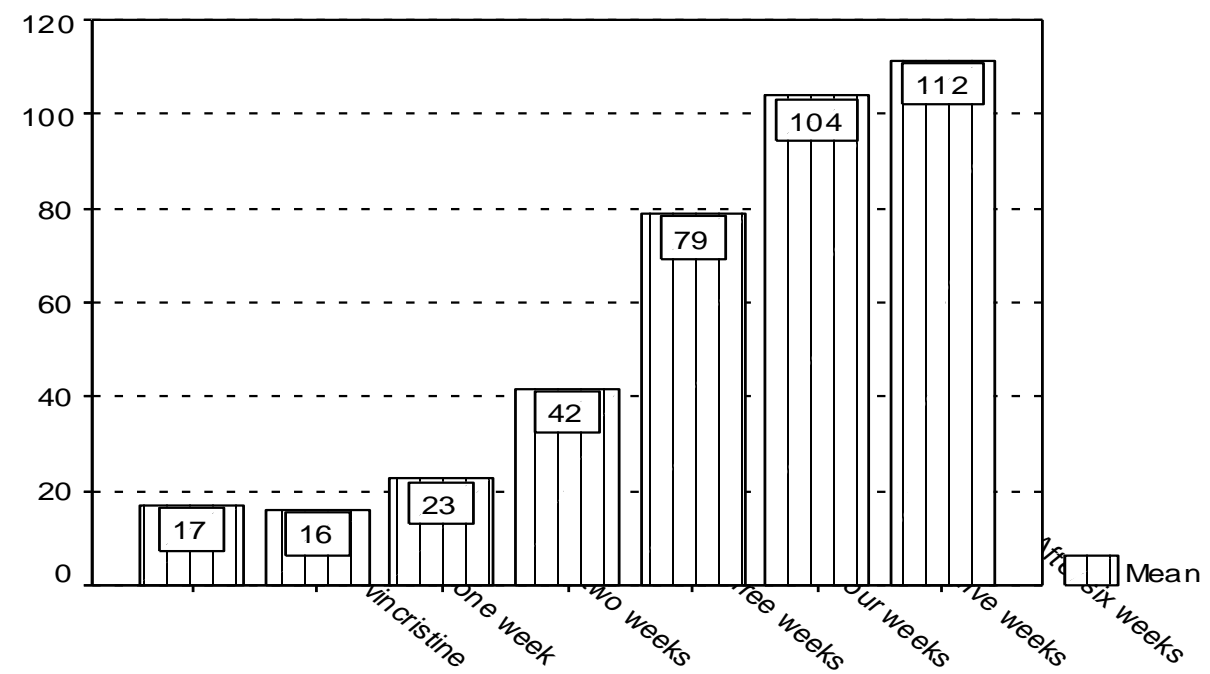

Figure 2 B :Referactory splenecto mized ITP patients

Table 3 : Comparison of the mean platelet count before and after vincristine treatment In non splenectomized ITP patients

\begin{tabular}{|c|c|c|c|c|c|c|}
\hline \multirow{2}{*}{$\begin{array}{c}\text { Variables } \\
(\text { No=21 } \\
\text { patients })\end{array}$} & \multicolumn{6}{|c|}{ After Vincristine treatment } \\
\hline & $\begin{array}{l}\text { After } 1^{\text {st }} \\
\text { week }\end{array}$ & $\begin{array}{l}\text { After } 2^{\text {nd }} \\
\text { week }\end{array}$ & $\begin{array}{l}\text { After } 3^{\text {rd }} \\
\text { week }\end{array}$ & $\begin{array}{l}\text { After } 4^{\text {th }} \\
\text { week }\end{array}$ & $\begin{array}{l}\text { After } 5^{\text {th }} \\
\text { week }\end{array}$ & $\begin{array}{l}\text { After } 6^{\text {th }} \\
\text { week }\end{array}$ \\
\hline \multirow[b]{2}{*}{$\begin{array}{c}\text { Platelet } \\
\text { count } \\
(\mathrm{Mean} \pm \mathrm{SD} \\
\mathbf{x 1 0} 9 / \mathbf{L})\end{array}$} & $11.4 \pm 5.1$ & $16.7 \pm 7.2$ & $37.1 \pm 22.47$ & $53.76 \pm 34.82$ & $94.86 \pm 71.29$ & $80.03 \pm 60.73$ \\
\hline & \multicolumn{6}{|c|}{$\begin{array}{l}\text { Before Vincristine treatment } \\
\qquad 11.3 \pm 6.1\end{array}$} \\
\hline P-value & NS & $*$ & $* *$ & $* *$ & $* *$ & $* *$ \\
\hline
\end{tabular}

Wilcoxon test was used NS: not significant, $*$ : significant $(\mathrm{p}<0.05),{ }^{*}$ : highly significant $(\mathrm{p}<0.001)$

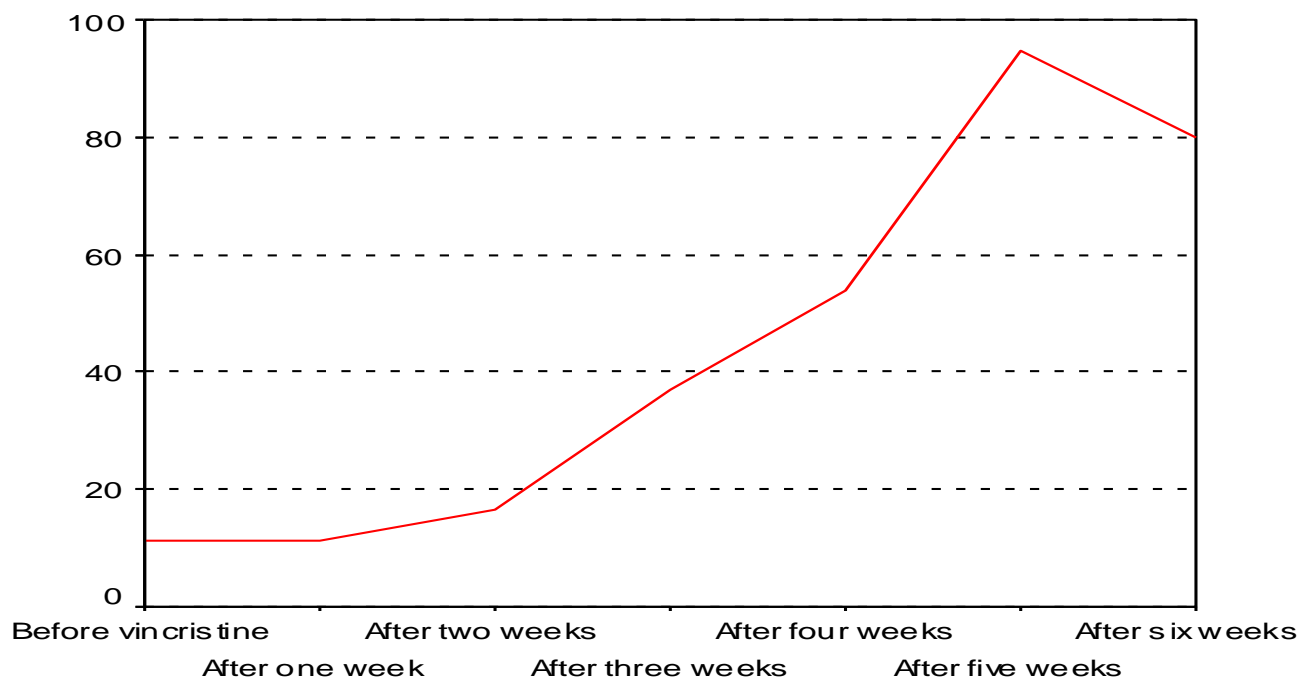

Figure 3 :Mean platelet count in non splenctomized ITP patients 
There was statistically significant increase of the mean platelet count in group II after the $3^{\text {rd }}, 4^{\text {th }}, 5^{\text {th }}$ and $6^{\text {th }}$ weeks of vincristine treatment than before the use of vincristin with $(p<0.05)$ for all comparison, while no significant statistical difference was detected after the $1^{\text {st }}$ and $2^{\text {nd }}$ week of vincristine treatment when compared with before the use of vincristine treatment (table $4 \&$ figure 4 ) .

Table 4 : Comparison of the mean platelet count before and after vincristine treatment in splenectomized ITP patients

\begin{tabular}{|c|c|c|c|c|c|c|}
\hline \multirow[b]{2}{*}{$\begin{array}{c}\text { Variables } \\
(\mathrm{No}=8 \\
\text { patients })\end{array}$} & \multicolumn{6}{|c|}{ Vincristine treatment } \\
\hline & $\begin{array}{l}\text { After } 1^{\text {st }} \\
\text { week }\end{array}$ & $\begin{array}{l}\text { After } 2^{\text {nd }} \\
\text { week }\end{array}$ & $\begin{array}{l}\text { After } 3^{\text {rd }} \\
\text { week }\end{array}$ & $\begin{array}{l}\text { After } 4^{\text {th }} \\
\text { week }\end{array}$ & $\begin{array}{c}\text { After } 5^{\text {th }} \\
\text { week }\end{array}$ & $\begin{array}{l}\text { After }] \\
6^{\text {th }} \text { week }\end{array}$ \\
\hline \multirow[b]{2}{*}{$\begin{array}{c}\text { Platelet } \\
\text { count } \\
\text { (Mean } \pm \\
\text { SD } \\
\left.\times^{9} 10^{9} / \mathrm{L}\right)\end{array}$} & $16 \pm 3.5$ & $22.5 \pm 9.1$ & $41.75 \pm 25.79$ & $78.87 \pm 59.47$ & $103.87 \pm 79.11$ & $111.5 \pm 84.54$ \\
\hline & \multicolumn{6}{|c|}{$\begin{array}{l}\text { Before vincristine treatment } \\
\qquad(17 \pm 4.53)\end{array}$} \\
\hline P-value & NS & NS & $*$ & $*$ & $*$ & $*$ \\
\hline
\end{tabular}

Wilcoxon test was used NS: not significant, *: significant $(\mathrm{p}<0.05)$

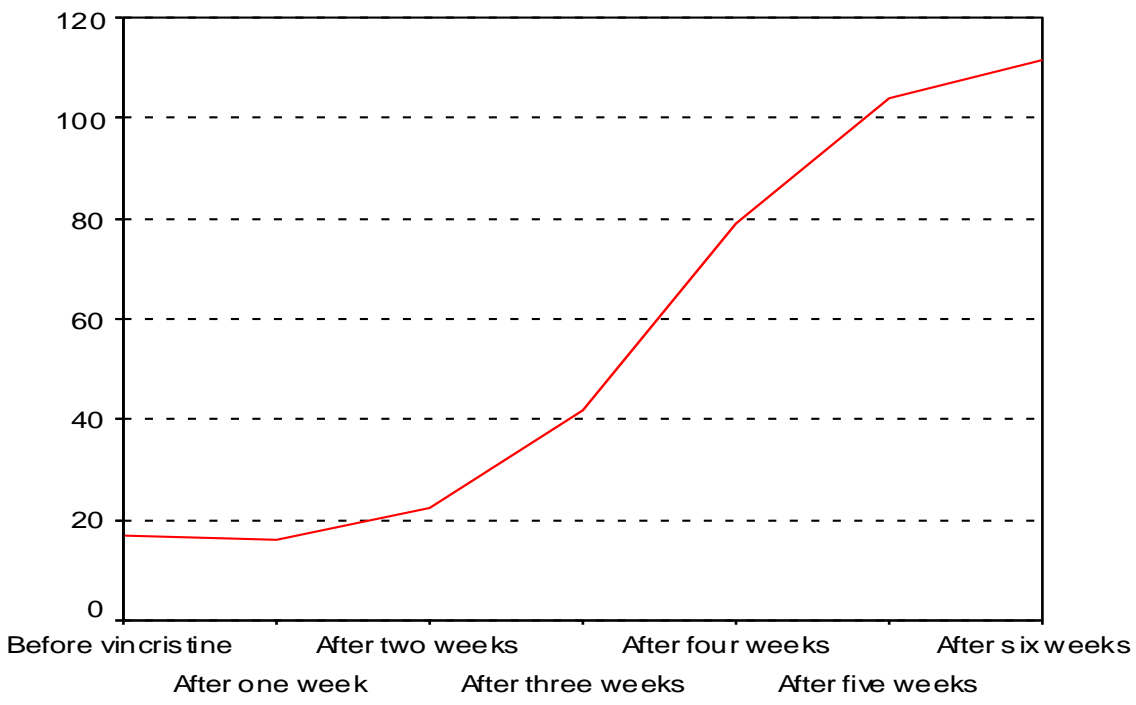

Figure 4 :Mean platelet count in referactory splenectomized ITP patients

Table 4 revealed that when the both groups were compared to each other, group II had a significantly increased mean platelet count than group I after the $4^{\text {th }}$ week of vincristine treatment with $(p<0.05)$, while no significant differences could be detected after the $1 \mathrm{st}, 2 \mathrm{nd}, 3 \mathrm{rd}, 5^{\text {th }}$ and $6^{\text {th }}$ weeks of vincristine treatment (table 5 \& figure 5) . 
Table 5: Effect of vincristine treatment on the platelet count between Splenectomized and non splenectomized ITP patients

\begin{tabular}{|c|c|c|}
\hline Variables & $\begin{array}{c}\text { Mean platelet + SD } \\
\text { X } 109 \text { L }\end{array}$ & P-value \\
\hline $\begin{array}{l}\text { Before vincristine therapy } \\
\text { - } \quad \text { Non splenectomized }(\mathrm{no}=21) \\
\text { - } \quad \text { Splenectomized }(\mathrm{no}=8)\end{array}$ & $\begin{array}{c}11.33+6.1 \\
17 \pm 4.53\end{array}$ & NS \\
\hline $\begin{array}{l}\text { After one week } \\
\text { - } \quad \text { Non splenectomized }(\mathrm{no}=21) \\
\text { - } \quad \text { Splenectomized }(\mathrm{no}=8)\end{array}$ & $\begin{array}{c}11.38+5.09 \\
16 \pm 3.51\end{array}$ & NS \\
\hline $\begin{array}{l}\text { After two weeks } \\
\text { - } \quad \text { Non splenectomized }(\mathrm{no}=21) \\
\text { - } \quad \text { Splenectomized }(\mathrm{no}=8)\end{array}$ & $\begin{array}{c}16.71 \pm 7.2 \\
22.5 \pm 9.134\end{array}$ & NS \\
\hline $\begin{array}{l}\text { After three weeks } \\
\text { - } \quad \text { Non splenectomized }(\mathrm{no}=21) \\
\text { - } \quad \text { Splenectomized }(\mathrm{no}=8)\end{array}$ & $\begin{array}{l}37.1 \pm 22.47 \\
41.75 \pm 25.8\end{array}$ & NS \\
\hline $\begin{array}{l}\text { After four weeks } \\
\text { - } \quad \text { Non splenectomized }(\mathrm{no}=21) \\
\text { - } \quad \text { Splenectomized }(\mathrm{no}=8)\end{array}$ & $\begin{array}{l}53.77 \pm 34.82 \\
78.88 \pm 59.47\end{array}$ & $*$ \\
\hline $\begin{array}{l}\text { After five weeks } \\
\text { - } \quad \text { Non splenectomized }(\mathrm{no}=21) \\
\text { - } \quad \text { Splenectomized }(\mathrm{no}=8)\end{array}$ & $\begin{array}{c}94.86 \pm 71.29 \\
103.88 \pm 79.11\end{array}$ & NS \\
\hline $\begin{array}{l}\text { After six weeks } \\
\text { - } \quad \text { Non splenectomized }(\mathrm{no}=21) \\
\text { - } \quad \text { Splenectomized }(\mathrm{no}=8)\end{array}$ & $\begin{array}{c}80.1 \pm 60.73 \\
111.5 \pm 84.59\end{array}$ & $\begin{array}{c}\mathrm{NS} \\
\mathrm{P}=0.055\end{array}$ \\
\hline
\end{tabular}

Mann-Whitney U test was used NS: not significant, *: significant $(\mathrm{p}<0.05)$

Table 5 shows that mean platelet count after 2, 4 and 6 months of stoppage of vincristine treatment in group I were $(68.67 \pm 62.9,62.095 \pm 63.63$ and $61.86+67.32)$ respectively, and in group II were $(118 \pm 89.52$, $117.16 \pm 89.54$ and $104.63 \pm 79.18$ ) respectively (table 6 and figure $6 \mathrm{~A} \& \mathrm{~B}$ ) . 
Table 6: Follow up of platelet count after stoppage of vincristine therapy

\begin{tabular}{|c|c|c|}
\hline Variables & $\begin{array}{l}\text { Mean platelet count } \\
+ \text { SD X } 10^{9} \mathrm{~L}\end{array}$ & P-value \\
\hline $\begin{array}{l}\text { Before vincristine therapy } \\
\text { - } \quad \text { Non splenectomized }(\mathrm{no}=21) \\
\text { - } \quad \text { Splenectomized }(\mathrm{no}=8)\end{array}$ & $\begin{array}{l}11.33 \pm 6.05 \\
17 \pm 4.54\end{array}$ & \\
\hline $\begin{array}{l}\text { After six weeks of vincristine treatment } \\
\text { - } \quad \text { Non splenectomized }(\mathrm{no}=21) \\
\text { - } \quad \text { Splenectomized }(\mathrm{no}=8)\end{array}$ & $\begin{array}{c}80.1 \pm 60.73 \\
111.5 \pm 84.59\end{array}$ & $* *$ \\
\hline $\begin{array}{l}\text { Platelet count after } \mathbf{2} \text { months of stoppage of } \\
\text { vincristine therapy } \\
\text { - } \quad \text { Non splenectomized }(\text { no }=21) \\
\text { - } \quad \text { Splenectomized }(\mathrm{no}=8)\end{array}$ & $\begin{array}{c}68.67 \pm 62.9 \\
118 \pm 89.52\end{array}$ & $*$ \\
\hline $\begin{array}{l}\text { Platelet count after } \mathbf{4} \text { months of stoppage of } \\
\text { vincristine therapy } \\
\text { - } \quad \text { Non splenectomized }(\mathrm{no}=21) \\
\text { - } \quad \text { Splenectomized }(\mathrm{no}=8)\end{array}$ & $\begin{array}{l}62.095 \pm 63.63 \\
117.13 \pm 89.54\end{array}$ & $*$ \\
\hline $\begin{array}{l}\text { Platelet count after } 6 \text { months of stoppage of } \\
\text { vincristine therapy } \\
\text { - } \quad \text { Non splenectomized }(\text { no }=21) \\
\text { - } \quad \text { Splenectomized }(\text { no }=8)\end{array}$ & $\begin{array}{c}61.86+67.32 \\
104.63 \pm 79.18\end{array}$ & $*$ \\
\hline
\end{tabular}

Mann-Whitney U test was used NS: not significant, *: significant $(\mathrm{p}<0.05)$

Table 6 shows that there was statistically significant persistent increase of the mean platelet count after 2,4 and 6 months of stoppage of vincristine treatment when compared with the mean platelet count before the use of vincristin treatment in group I with $(\mathrm{p}<0.001, \mathrm{p}<0.05$ and $\mathrm{p}<0.05)$ respectively and in group II with $(\mathrm{p}<0.05)$ for all comparisons (table $6 \&$ figure 6 A and B) .

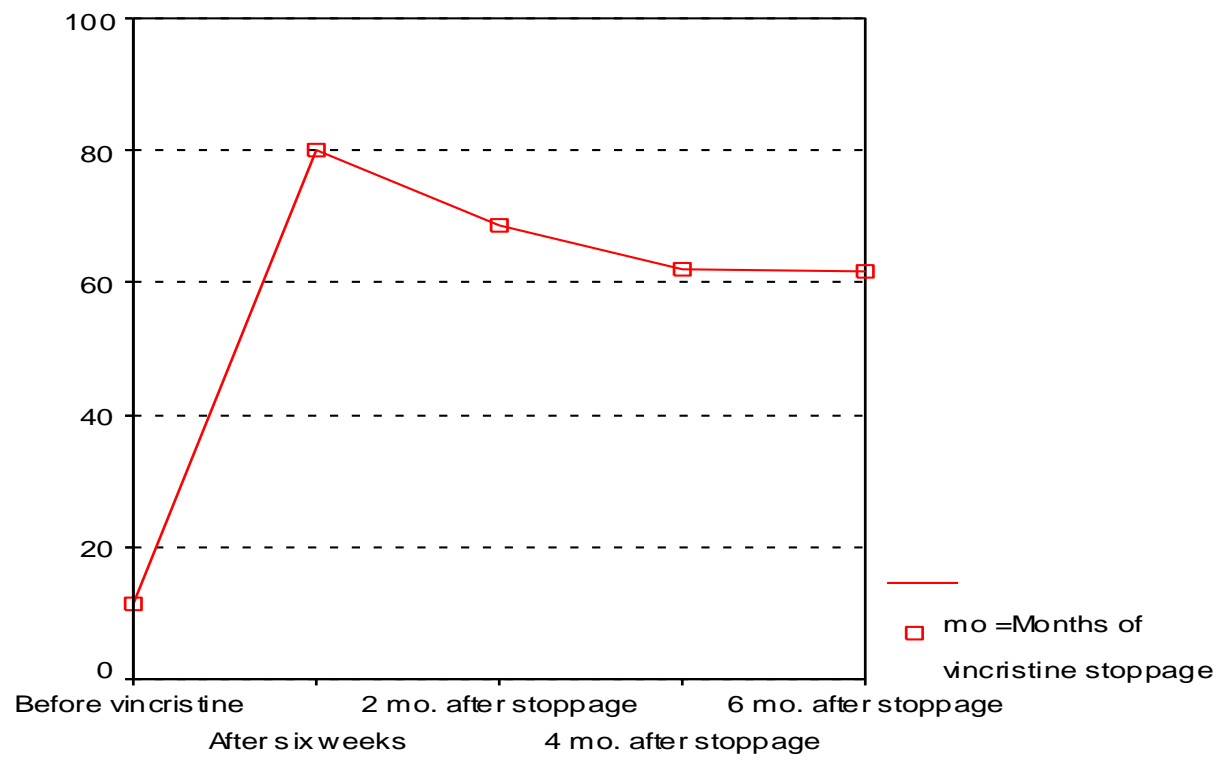

Figure 6A: Mean platelet count before and after stoppage of vincristine therapy in non splenectomized ITP patients 


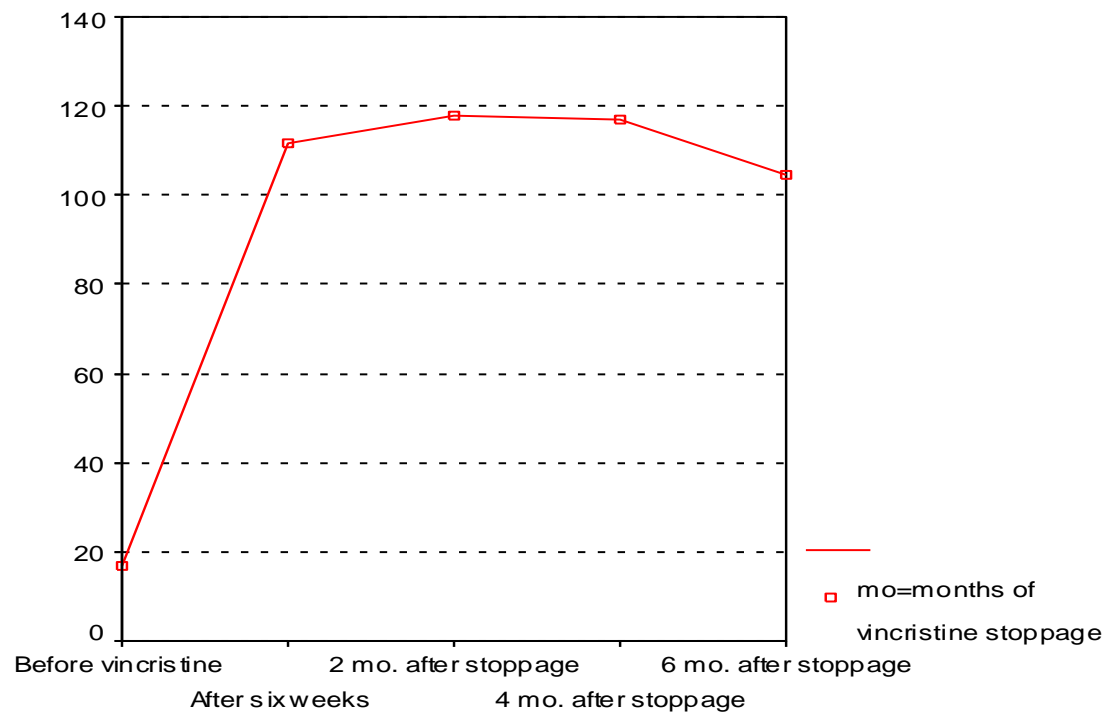

Figure 6B: Mean platelet count before and after stoppage of vincristine therapy in splenectomized ITP patients

Table 7: Comparison of mean platelet count before and after Stoppage of vincristine treatment in all studied patients

\begin{tabular}{|c|c|c|c|c|}
\hline \multicolumn{2}{|c|}{ Variables } & \multicolumn{3}{|c|}{ Stoppage of vincristine } \\
\hline & & After 2 months & After 4 months & After 6 months \\
\hline 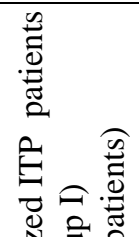 & \multirow[t]{2}{*}{$\begin{array}{c}\text { Platelet count } \\
(\text { Mean } \underset{9}{ \pm} / \mathrm{SD})\end{array}$} & $68.67 \pm 62.9$ & $62.095 \pm 63.63$ & $61.86+67.32$ \\
\hline 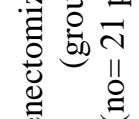 & & \multicolumn{3}{|c|}{$\begin{array}{l}\text { Before vincristine treatment } \\
\qquad(11.33 \pm 6.05)\end{array}$} \\
\hline $\begin{array}{l}2 \\
\text { के } \\
\text { है } \\
\text { z }\end{array}$ & $\mathrm{P}$ value & $* *$ & $*$ & $*$ \\
\hline \multirow{3}{*}{ 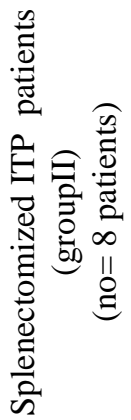 } & \multirow{2}{*}{$\begin{array}{c}\text { Platelet count } \\
(\text { Mean } \underset{9}{ \pm} / \mathrm{L})\end{array}$} & $118 \pm 89.52$ & $117.13 \pm 89.54$ & $104.63 \pm 79.18$ \\
\hline & & \multicolumn{3}{|c|}{$\begin{array}{l}\text { Before vincristine treatment } \\
\qquad(17 \pm 4.54)\end{array}$} \\
\hline & $P$ value & $*$ & $*$ & $*$ \\
\hline
\end{tabular}

Wilcoxon test was used NS: *: significant $(\mathrm{p}<0.05),{ }^{* *}$ : highly significant $(\mathrm{p}<0.001)$ 


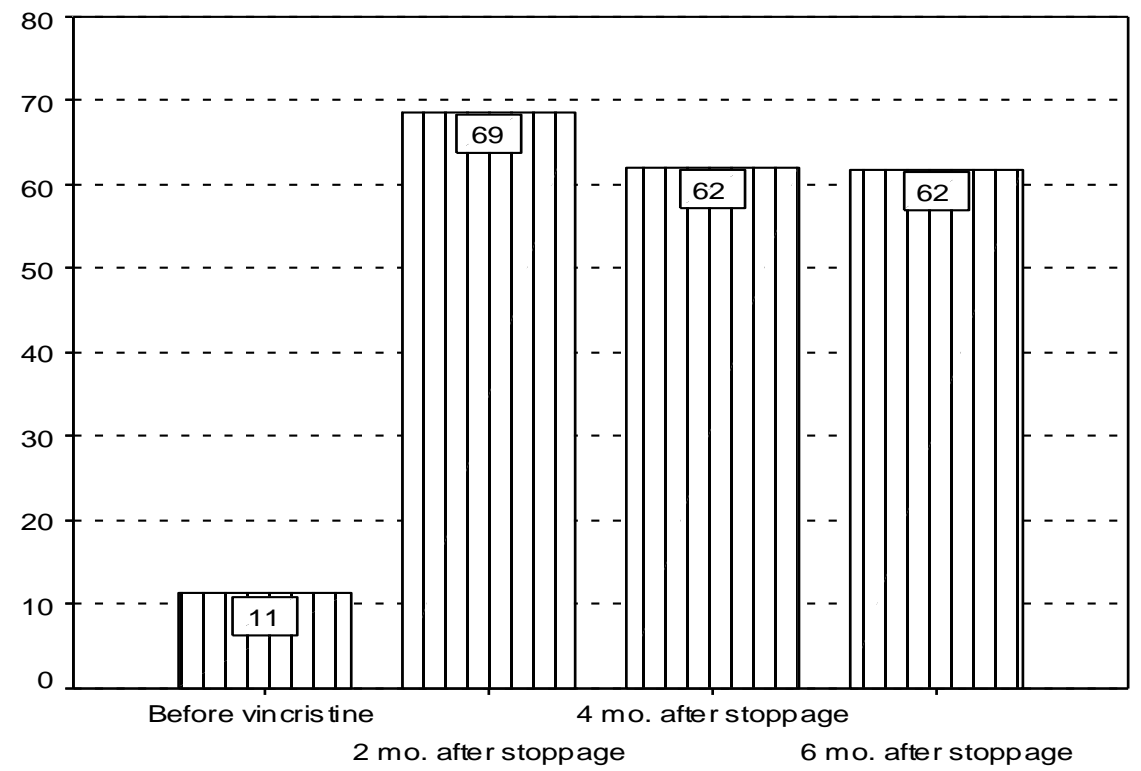

Figure 7A: Mean platelet count before and after stoppage of vincristine treatment in non splenectomized ITP patients

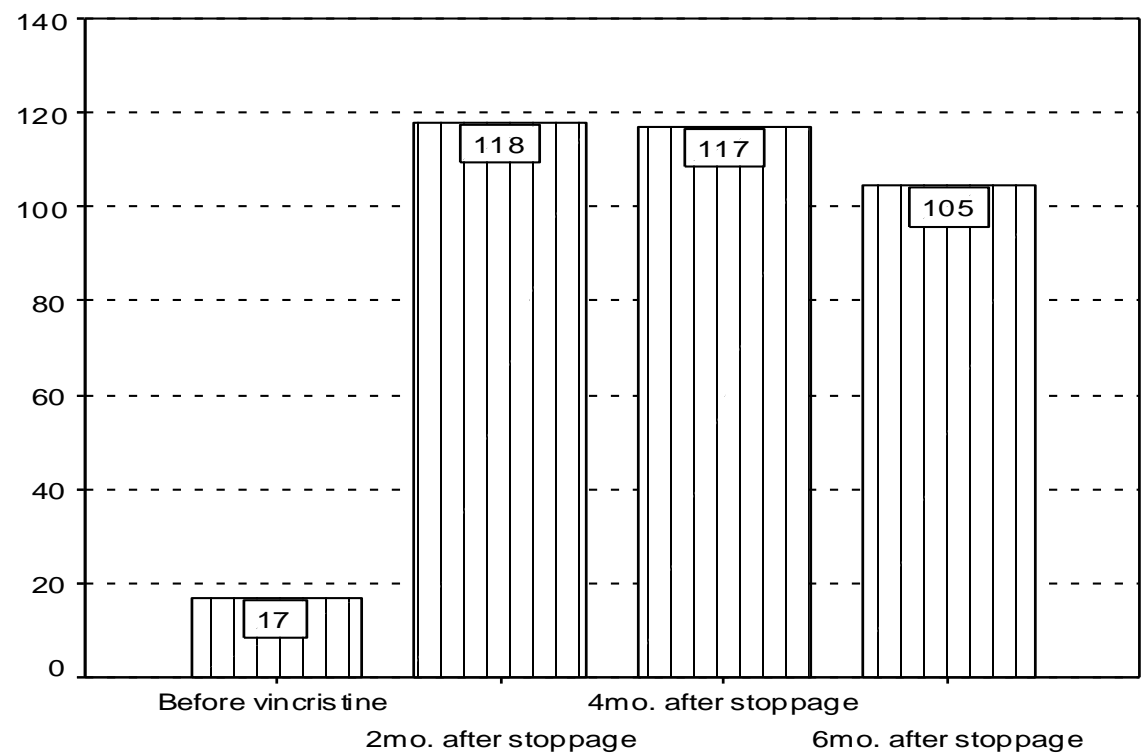

Figure 7B: Mean platelet count before and after stoppage of vincristine treatment in splenectomized ITP patients 
Table 8: Comparison of the mean platelet count between splenectomized and non splenectomized ITP patients after stoppage of vincristine treatment

\begin{tabular}{|c|c|c|}
\hline Variables & Mean platelet + SD X $10^{9} \mathrm{~L}$ & P value \\
\hline $\begin{array}{ll}\text { Before } & \text { vincristine therapy } \\
- & \text { Non splenectomized }(\mathrm{no}=21) \\
& \text { Splenectomized }(\mathrm{no}=8)\end{array}$ & $\begin{array}{c}11.33+6.1 \\
17 \pm 4.53\end{array}$ & NS \\
\hline $\begin{array}{ll}\text { After } 2 & \text { months of stoppage of vincristine } \\
\text { - } & \text { Non splenectomized }(\text { no }=21) \\
\text { Splenectomized }(\text { no }=8)\end{array}$ & $\begin{array}{c}68.67 \pm 62.9 \\
118 \pm 89.52\end{array}$ & $*$ \\
\hline $\begin{array}{l}\text { After } 4 \text { months of stoppage of vincristine } \\
\text { - } \quad \text { Non splenectomized }(\text { no }=21) \\
\text { Splenectomized }(\text { no }=8)\end{array}$ & $\begin{array}{l}62.095 \pm 63.63 \\
117.13 \pm 89.54\end{array}$ & $\begin{array}{c}\mathrm{NS} \\
\mathrm{P}=0.069\end{array}$ \\
\hline $\begin{array}{l}\text { After } 6 \text { months of stoppage of vincristine } \\
\text { - } \quad \text { Non splenectomized }(\text { no }=21) \\
\text { - } \quad \text { Splenectomized }(\text { no }=8)\end{array}$ & $\begin{array}{c}61.86+67.32 \\
104.63 \pm 79.18\end{array}$ & NS \\
\hline
\end{tabular}

Mann-Whitney U test was used NS: not significant, *: significant $(\mathrm{p}<0.05)$

Table 8 shows that there was higher mean value of platelet count was observed after 4 and 6 months of stoppage of vincristine treatment among group II than group I with no statistically significant difference, while there was statistically significant differences when they compared after 2 months of stoppage of vincristine with $(\mathrm{p}<0.05)$ table 8$)$.

\section{Discussion:}

Idiopathic thrombocytopenic purpura (ITP) is an autoimmune disorder mediated by the production of autoantibodies directed against platelets (Provan et al., 2010) with a variable clinical course (Stiakaki et al.,2012) as suggested by the demonstration of IgG-type anti-platelet antibodies (Karpatkin et al., 1972) . Based on the fact that ITP is generally caused by antibodies, immunosuppresive agents may be useful in refractory ITP with serious disease, as well as in patients unsuitable for surgery and for corticosteroids (Finch et al., 1974). Cyclophosphamide and azathioprine have been for many years the first choice agents ( Rosse, 1978). However, they have the disadvantage of the long duration of treatment required, and their myelo-toxicity ( Ahn et al.,1978). Other agents such as metho-trexate, chlorambucil, 6 mercaptopurine, actino-mycin C, Lasparaginase and thioguanine, have been used generally with disappointing results and In the last years, the Vinca alkaloids have been increasingly used in refractory ITP ( Ahn et al., 1978 and Sikorska et al.,2004). Among the Vinca alkaloids, vincristine appears to offer the best results with fewer side effects (Robertson and McCarthy, 1969).

Patients with primary immune thrombocytopenia (ITP) may require treatment to reduce the risk of serious bleeding if platelets remain consistently low. While approximately $70-80 \%$ of patients respond to an initial course of corticosteroids, relapse is common. For steroid-refractory patients, there is a choice between surgical splenectomy and further medical treatments, based on many factors including the patient's bleeding history, fitness for surgery, comorbidities, tolerance of adverse events, lifestyle and preferences (Stasi et al ., 2010). Splenectomy is currently employed as a second line therapy; however it is ineffective in about $30-40 \%$ of the cases. Also these therapies present an increasing risk for opportunistic infection and post surgical complications during their treatment courses and adversely affect the overall outcomes(Stasi et al ., 2010).

The decision whether to proceed to splenectomy or try other medical therapies in corticosteroidrefractory ITP patients remains patient-specific. Splenectomy has its risks (including perioperative and longterm risks), and relapse/non response are relatively common, but it offers the possibility of cure in the majority of patients. However, newer treatments may potentially allow splenectomy to be deferred for prolonged periods, as well as providing alternative treatment options for patients who fail splenectomy(Stasi et al ., 2010).

Currently, there is a trend towards a decreased rate of splenectomy in ITP (George, 2006). Although a safe procedure in the vast majority of patients, complications include surgical mortality, thromboembolic events, and overwhelming sepsis, and the long-term effects remain poorly understood (Dolan et al, 2007). With the emergence of alternative therapies, clinicians increasingly consider delaying splenectomy until later in the course of the disease to allow more time for spontaneous resolution (Cooper et al ., 2002, George et al., 2003 and Kuter et al, 2008). Thus, it is essential to evaluate the role of vincristine in treating (splenectomized and non splenectomized) refractory ITP patients who are resistant to corticosteroids therapy or who have contraindications to their use with no available other lines of treatment especially with higher costs of other lines 
of treatment as immunoglobulin and also to assess the long term (6 months) follow up platelet count after stoppage of vincristine treatment.

This study included twenty nine refractory ITP patients with maximum dose of corticosteroids and even after high dose of dexamethason ( 21 of them non-splenectomized "group I" and the remaining 8 splenectomized " group II") were treated with two- hour intravenous infusion of vincristine (1-2 mg) once a week for 6 weeks. In every patient, the platelet count was evaluated just before and after the infusion of vincristine, follow up of those patients for 6 months after stoppage of vincristine were evaluated by platelet count every 2 months . Patients with hepatitis and chronic liver diseases were excluded from this study.

The results of this study were in agreement with the majority of studies, which mostly showed a rise in the platelet count in refractory ITP patients treated with vincristine. This result found that the mean platelet count increased significantly among non splenectomzed patients after the use of vincristin, this in agreement with Sikorska et al.,2004 study, who reported, a rise in the platelet count of at least $100 \times 10^{9} / \mathrm{L}$ with statistically significant improvement $(\mathrm{P}<0.01)$ in refractory ITP patients treated with vincristine, also with Cervantes et al., 1980 and Linares et al., 1988 who reported that vincristine may be the therapy of choice in the management of refractory ITP and with Matsushima et al.(1992) who reported that vincristine therapy was considered to be an useful treatment in elderly patients with ITP. The same results were observed in Szczepanik et al. (2007) study in their evaluation of the efficacy of vinca alkaloids in preparing adult corticosteroid refractory chronic ITP patients for splenectomy and they reported that $75 \%$ of their treated patients the platelet count increased to $\geq 80 \times 10^{9} / 1$, which allowed safe splenectomy and they added that , matching of vincristine costs with treatment efficacy and comparison with similar costs for intravenous immunoglobulin treatment revealed many folds lower costs of the vincristine method.

This results were to some extent in agreement with Fenaux et al. (1990) who concluded that slow infusions of vincristine may be a useful approach in ITP of recent onset, but they added that in their experience, this treatment has limited benefit in chronic ITP, in contrary to our results in which our patients were chronic ITP and showed good response .Also our result partially in agreement with Simon et al.(1987) who reported a complete remission in all ITP patients after vincristine therapy but in our study not all patient get in complete remission.Treatment of patients' refractory to splenectomy (with absence of response or relapse after initial response) is difficult, and their long-term outcome is not well known (Bourgeois et al., 2003).

So it was important to study the effect of vincristine in splenectomized refractory ITP patients.Our results showed a significant increase of the mean platelet count in splenectomized refractory ITP patients after the $3^{\text {rd }}, 4^{\text {th }}, 5^{\text {th }}$ and $6^{\text {th }}$ weeks of vincristine treatment, this results were in agreement with Bethan and James.( 2008) who stated that A proportion of patients will be truly refractory to splenectomy, and require further treatment with immunosuppressive second-line therapies as vincristine. This results also were to some extent in agreement with Shvidel et al.( 2006) who used vincristine-loaded platelet infusion in patients with refractory (ITP)who failed to respond to two to six different treatment modalities, including corticosteroids and splenectomy, their results suggested that this inexpensive and well-tolerated treatment may be a useful approach in patients with ITP and with Simon et al.(1987) who reported a good response with vincristine treatmnt In 12 cases of refractory chronic ITP (of whom 10 had been splenectomized) .

This study revealed that vincristine may be effective line of treatment in referactory splenectomized patients than non splenectomized patients and this differences was noted significantly after the $4^{\text {th }}$ week of vincristine treatment $(\mathrm{p}<0.05)$, more studies needed to confirm this result as no available studies compared those groups of patient . But it has been pointed out in Ries. (1976) that vincristine could be more effective in splenectomized patients.

In this study a persistent increase of the mean platelet count was observed in both groups of patients after stoppage of vincristine treatment for 6 months when compared with the mean platelet count before the use of vincristin treatment, these results were in agreement with Linares et al.( 1988) who reported that referactory ITP patients showed a return to normal platelet counts maintained for 3 months or longer after vincristine treatment.Also these results were partially in agreement with Manoharan. (1986) study who reported that Vincristine therapy appears to be therapeutically beneficial and can achieve sustained recovery of platelet count in patients with ITP of less than six months duration, in contrary to this result in which good response maintained up to 6 months after stoppage of vincristine therapy. This may be explained by that their patients were 10 patients only and they received vincristine at weekly intervals for 4 weeks only in contrary of our patients who received vincristine for 6 weeks. The duration of vincristine treatment may play a role in sustained recovery of platelet count and this point need more studies?

These results disagree with that of Kueh. (1982) who reported the duration of platelet response to vincristine without concomitant azathioprine therapy was less than 10 weeks in contrary to this result in which sustained recovery of platelet count maintained up to 6 months after stoppage of vincristine therapy .This may be explained by that their patients were 12 patients and they received weekly $(1 \mathrm{mg})$ vincristine injections to a cumulative dose not greater than $3 \mathrm{mg}$, but in this study we use vincristine (1-2 mg) up to 6 weeks. The duration 
of vincristine treatment in addition of the cumulative dose of vincristine may play a role in sustained recovery of platelet count.

Higher mean value of platelet count was observed after 4 and 6 months of stoppage of vincristine treatment among splenectomized more than non splenectomized patients, this comparison was statistically significant after 2 months of stoppage of vincristine treatment ( $p<0.05$ ). It seems to be that splenectomized ITP patients may has sustained recovery of platelet after vincristine stoppage more than non splenectomized patients, more studies needed to confirm this result as no available studies compared those groups of patient

\section{Conclusion:}

Administration of vincristine to chronic corticosteroid refractory immune thrombocytopenia (ITP) patients result in increase platelet count to a significant level and could be used in situations requiring increase of the platelet count in patients who failed to response to maximum dose of corticosteroid-therapy and or splenectomy, especially with limited resources with no available other lines of treatment and also in patients who in need to do surgical intervention.

\section{References}

[1] Ahn Y, Byrnes J, Harrington W, Cayer M , Smith D , Brunskill D and Pall L:The treatment of idiopathic thrombocytopenia with vinblastine-loaded platelets. New England Journal of Medicine. 1978 ; 298, 1101.

[2] Ahn Y, Harrington W, Seelman R and Eytel C : Vincristine therapy of idiopathic and secondary thrombocytopenias. New England Journal of Medicine. 1974; 291, 376.

[3] Alhossain Khalafallah, Zafreen Rahman, Kath Ogden and Terry Hannan :Successful Treatment with Thrombopoietin Receptor Agonist in Avoiding Splenectomy for Patients with Chronic Refractory Immune Thrombocytopenia. Mediterr J Hematol Infect Dis. 2012; 4(1): e2012003

[4] Bethan P AND James B. : REFRACTORY IMMUNe thrombOCYTOPENIC PURPURA: CURRENT STRATEGIES FOR inVESTIGATION AND MANAGEMENT .BRitish Journal of HAEMATOlOgy . 2008; Volume 143, ISSue 1, PAGes 16-26, OCTOBER .

[5] Bourgeois E, Caulier MT, Delarozee C, Brouillard M, Bauters F and Fenaux P:Long-term follow-up of chronic autoimmune thrombocytopenic purpura refractory to splenectomy: a prospective analysis. Br J Haematol. 2003 Mar;120(6):1079-88.

[6] British Committee for Standards in Haematology General Haematology Task Force: Guidelines for the investigation and management of idiopathic thrombocytopenic purpura in adults, children and in pregnancy. Br J Haematol. 2003; 120: 574-96.

[7] Burton I , Roberts B , Child J, Montgomery D and Raper C : Responses to vincristine in refractory idiopathic thrombocytopenic purpura. British Medical Journal .1976; 2, 918

[8] Cervantes C., Rozman E., Feliu E., Montserrat C., Diumenjo A. And Gran4ena : Low-dose vincristine in the treatment of corticosteroid-refractory idiopathic thrombocytopenic purpura (ITP) in non-splenectomized patients. Postgraluate Medical Journal $.1980 ; 56,711-714$.

[9] Cindy N, Wendy L , Mark C, Alan C, Lawrence S and Mark A :The American Society of Hematology 2011 evidence-based practice guideline for immune thrombocytopenia. Blood. April 21, 2011; vol. 117 no. 16 4190-4207

[10] Cooper, N., Woloski, B.M., Fodero, E.M., Novoa, M.V., Leber, M., Beer, J.H. \& Bussel, J.B: Does treatment with intermittent infusions of anti-D allow a proportion of adults with recently diagnosed immune thrombocytopenic purpura to avoid splenectomy? Blood. 2002; 99, 1922-1927.

[11] Cooper N and Bussel J: The pathogenesis of immune thrombocytopenic purpura. Br J Haematol. 2006; 133: 364-74.

[12] Dolan, J.P., Sheppard, B.C. and DeLoughery, T.G : Splenectomy for immune thrombocytopenic purpura: surgery for the $21 \mathrm{st}$ century. American Journal of Hematology. 2007; 83, 93-96.

[13] Fenaux P, Quiquandon I, Caulier MT, Simon M, Walter MP and Bauters F: Slow infusions of vinblastine in the treatment of adult idiopathic thrombocytopenic purpura: a report on 43 cases. Blut. 1990; Apr;60(4):238-41.

[14] Finch S, Castro O, Cooper M, Covey W, Erichson R and Mcphedran P : Immunosuppressive therapy of chronic idiopathic thrombocytopenic purpura. American Journal of Medicine . 1974; 56, 4.

[15] George, J.N: Management of patients with refractory immune thrombocytopenic purpura. Journal of Thrombosis and Haemostasis .2006; 4, 1664-1672

[16] George J : Definition, diagnosis and treatment of immune thrombocytopenic purpura. Haematologica . 2009; 94: 759-62.

[17] George, J., Raskob, G., Vesely, S., Moore, D.J., Lyons, R.M., Cobos, E., Towell, B., Klug, P. and Guthrie, T: Initial management of immune thrombocytopenic purpura in adults: a randomized controlled trial comparing intermittent anti-D with routine care. American Journal of Hematology . 2003 ;73, 135-140.

[18] Karpatkin S , Strick N , and Suskind G : Detection of splenic antiplatelet antibody synthesis in idiopathic autoimmune thrombocytopenic purpura (ITP).British Journal of Haematology. 1972; 23, 167.

[19] Kueh YK : Vincristine therapy in refractory chronic idiopathic thrombocytopenic purpura. Ann Acad Med Singapore. 1982 Apr;11(2):290-3.

[20] Kuter, D.J., Bussel, J.B., Lyons, R.M. and Pullarkat, V et al : Efficacy of romiplostim in patients with CHRONIC IMMUNE THROMBOCYTOPENIC PURPURA: A DOUBLE-BLIND RANDOMISED CONTROLLED TRIAL. LANCET .2008; 371, 395-403

[21] Linares M, Cervero A, Sanchez M, Garcia S, Miguel-Sosa A, Miguel-Garcia A and Miguel-Borja JM: Slow infusion of vincristine in the treatment of refractory thrombocytopenic purpura. Acta Haematol. 1988;80(3):173-4.

[22] Manoharan A :Slow infusion of vincristine in the treatment of idiopathic thrombocytopenic purpura. Am J Hematol. 1986 ; Feb;21(2):135-8.

[23] Matsushima T, Tamura J, Sawamura M, Nagumo T, Murakami H, Naruse T, Tsuchiya J , Nihon R and Igakkai Z :Successful treatment with vincristine for an elderly patient with idiopathic thrombocytopenic purpura. 1992 Jul-Aug;29(7-8):574-8. Japanese.

[24] Murat A, Ozlem S, Sahika , Ayla G, Funda C, Osman Y, Simten D, Meltem A and Gulsum O: Evaluation of 143 Cases of Immune Thrombocytopenic Purpura With Regards to Clinical Course and Response to Treatment. EAJM . 2010; 42: 120-3. 
[25] Provan D, Stasi R, Newland AC et al. : International consensus report on the investigation and management of primary immune thrombocytopenia. Blood. 2010;115(2):168-186

[26] Ries C: Vincristine for treatment of refractory autoimmune thrombocytopenia. New England Journal of Medicine. 1976.295 , 1136.

[27] Robertson J and McCarthy G : Periwinkle alkaloids and the platelet-count. Lancet.1969 ii, 353.

[28] Rosse W: Selective chemotherapy of macrophages in the treatment of idiopathic thrombocytopenic purpura. New England Journal of Medicine. 1978; 298, 1139 .

[29] Shvidel L, Sigler E, Shtalrid M and Berrebi A : Vincristine-loaded platelet infusion for treatment of refractory autoimmune hemolytic anemia and chronic immune thrombocytopenia: rethinking old cures. Am J Hematol. 2006;81(6):423.

[30] Sikorska A, Słomkowski1 M, Maślanka2 K, Konopka1 L, and Górski1 T: The use of vinca alkaloids in adult patients with refractory chronic idiopathicthrombocytopenia Clinical \& Laboratory Haematology . 2004 ;Volume 26, Issue 6, pages 407-411.

[31] Simon M, Jouet JP, Fenaux P, Pollet JP, Walter MP and Bauters F: The treatment of adult idiopathic thrombocytopenic purpura. Infusion of vinblastine in ITP. Eur J Haematol. 1987 Sep;39(3):193-6.

[32] Stasi R, Newland A, Thornton $\mathbf{P}$ and Pabinger I: Should medical treatment options be exhausted before splenectomy is performed in adult ITP patients? A debate. Ann Hematol. 2010 Dec;89(12):1185-95.

[33] Stiakaki E, Perdikogianni C, Thomou C, Markaki EA, Katzilakis N, Tsirigotaki M and Kalmanti M: IDIOPATHIC THROMBOCYTOPENIC PURPURA IN CHILDHOOD: TWENTY YEARS OF EXPERIENCE IN A SINGLE CENTER. PEDIATR INT. 2012; MAR 13.

[34] Szczepanik1, A. Sikorska2, M. Slomkowski2, and L. Konopka2: The use of vinca alkaloids in preparation for splenectomy of corticosteroid refractory chronic immune thrombocytopenic purpura patients. International Journal of Laboratory Hematology. 2007; Volume 29, Issue 5, pages 347-351, October.

[35] Vesely S, Perdue J, Rizvi M, Terrell D and George J: Management of adult patients with persistent idiopathic thrombocytopenic purpura following splenectomy: a systematic review. Ann Intern Med. 2004; 140: 112-20. 